\title{
Quality Journey of Turkey from the Perspective of Language Teachers
}

Hayal Köksal

\begin{abstract}
Interest in quality improvement efforts has boomed during the past decade. Total Quality Management (TQM) based upon "PDCA (Plan-Do-Check-Act) Mindset" originated in the business world but it has gained tremendous popularity in educational institutions in recent years. The philosophy and practice of Quality education have become the center of discussions in academe across the world, especially in universities. This article focuses on the launching of the Quality Campaign in Turkey where all state schools under the Ministry of Education first adopted the campaign in 1999, but then largely resisted its implementation because it was perceived and often practiced as a top-down process. More recently, one of the most fundamental changes occurred in ELT (English Language Teaching) classes through the leadership of ELT teachers in a bottom-up approach. The aim of this paper is to provide a historical review of Quality Education in Turkey and share some insights with readers about its implementation.
\end{abstract}

Key words: ELTers, Quality, PDCA, Awareness, Special Interest Group

\section{Introduction}

$\mathrm{T}$ he concept and practice of Total Quality in Education (TQE) have been highly popular in educational reform movements and discussions around the world since the late 1980s. The movement started in industry and the servicesector but then migrated to schools. In Turkey, the participation of the Ministry of Education in the Quality Campaign along with all schools in the country_ almost all 650,000 at that time _ helped establish the notion of "change" in our educational establishments at the turn of the $21^{\text {st }}$ century. There have been many studies about TQE in Turkey since then. However, the application of TQM in schools and especially in the classrooms has not achieved high levels of success, and therefore success stories have been limited. There were many reasons for the initial lack of success of the movement, such as resistance among the teachers, unwillingness of the administrations, and lack of knowledge and understanding about the implementation of Total Quality in educational settings.
This paper shares a historical view of how concepts and practices of Quality Education have been applied in English Language Teaching (ELT) in Turkey, why some efforts were not successful, and why others were more effective. The target readers, Teachers of English Language Teaching, are referred to as "ELTers" for short within this article. The article consists of two main parts. The first part will share three various studies including the content and outcomes of an elective course "Quality in ELT" conducted by the writer at the Foreign Language Education Department (FLED) of the Educational Faculty of Bogazici University from 1998 to 2004. This part will also cover the aim and the activities of a non-profit voluntary professional organization "English Language Education (ELEA/Inged) and a Special Interest Group (SIG) within it. An international network (The Center for Schools of Quality) will also be described in this part. The second part will summarise the outcomes of those activities, the reflections of the instructor (writer), and some recommendations for future applications. 


\section{Quality journeys of teachers and schools in Turkey}

Quality is a life-long journey including all phases of life. With such a significant role Quality Education should start from a child's early steps such in family and kindergarten. Teachers, with their outstanding mission of training future leaders, have the most important charge of all. Teachers are at the top of teaching pyramid, along with a child's parents.

The Ministry of National Education (MEB) in Turkey launched a "Quality Campaign in Turkish Schools" in November 1999. All the top administrators of the Ministry participated in a series of training seminars about "Quality" conducted by authorities representing the Quality Association of Turkey. The aim of those training seminars was to establish the quality philosophy in the minds of the people starting from the top managers, school leaders and teachers. The movement has been continuing since then. However, the feedback gained after implementation of TQE in Turkish schools has shown that it has not been understood properly. Many teachers and principals considered it as a burden on them especially because they tried to implement it in a top-down process, which is antithetical to the Quality philosophy. During the first years of the implementation, the survey results showed a quite low resistance to the new system; however, surveys of 2009 and 2011 showed much higher levels of resistance (Köksal, 2011).

\section{Early attempts for system change in Turkey}

In late 1990s, not only teachers and school leaders but most of the parents were complaining about the weak and cumbersome educational system and the low quality of education in Turkish schools. A great outcry was made by educational partners demanding the improvement of education. So, the decision of the Ministry to start TQM in schools might be considered as a bottom-up request coming from the grassroots of the teachinglearning process, i.e., classrooms and schools. Within a relatively short time the directors of the Ministry, school principals, officials, department heads, support groups, teachers, parents and all the customer-supplier chains of each school environment would be involved in the "Quality Movement." It was believed that that "the quality philosophy" would naturally be internalized and owned by everyone in schools after a certain time, and steps would be taken toward its successful implementation. Thus, it was thought that everyone would start applying the gained philosophy to their personal and professional lives, with beneficial results.

However, that did not happen. Soon after the beginning of the change process, complaints began to emerge. Principals could not start the movement in their schools at once due to lacking information about the philosophy and the methods showing them how to begin. They empowered the teachers but teachers were not informed well about TQM either. Regional education directors sent many pages of statistical surveys to school principals, in order to get quantifiable data about the physical conditions of schools, explaining their reasoning using TQM procedures. That unfortunately created more confusion. In many schools, all school people including teachers, students and parents could not internalize the concept of quality because the advisors, coming either from business world or from the factories, had insufficient insight into the world of schools. Within the guiding team there were no educators who could explain educational terms and education-focused Quality methodologies. The required "awareness" concerning quality improvement needs of schools and even the community was created only in a relatively few schools, and those have achieved required positive changes.

Some developments were significant. For instance, the Ministry of NationalEducation noticed the need of an urgent and fundamental change in schools. Since they mostly focused on physical conditions, IT labs were opened in every school and Turkish schools were included in a main portal within the Ministry. In every school, the administration was asked to establish a quality committee consisting of vice principals, some teachers, and a member of the School-Parent Association. In this case, too, many considered that task as a burden and others who did take part in those commissions rarely contributed. However, some schools were lucky, for the schools principals believed in that system and showed a real leadership to motivate 
and support their people, acting in the capacity of a team member and exerting participatory leadership. The positive changes in those schools were significant. The mission, vision, policy and strategies were determined with the contribution of each group. SWOP Analyses were conducted. Parents were trained through weekend seminars and the school turned into a true school of quality. Teachers were supported to improve themselves and their methodologies. The business world was invited to support the schools as a key stakeholder.

But on a larger scale, the resistance was inevitable as it always is with fundamental changes. In order to understand the causes of resistance to TQM, the culture of Turkey and the history of TQE in the Turkish educational system need to be understood. The rest of this article addresses these questions after giving a brief summary of how initial steps were taken to create awareness of TQM in schools.

\section{Creating auality awareness}

\section{Quality improvement efforts within ELEA / INGED}

English Language Education Association İNGED/ ELEA was established in Ankara in 1995 for the teachers of English working in primary and secondary schools including the lecturers of higher educational institutions. It is an associate foundation of İatefl in UK, and TESOL in USA. I was one of the first members of it and have been one of the active members in the Istanbul region until the mid 2000s. Since TQM was one of the modern movements in the educational field, I aimed at founding a quality-focused Special Interest Group (SIG) within İNGED. "Quality in ELT" (Q-ELT) was proposed to the Governing Body of INGED in 1999 and it was approved.

The main goal of the SIG was to create "Quality Awareness" among ELTers in order to improve the quality of ELT classroom and to come together as a professional group to share experiences. ELTers learn not only a foreign language during their pre-service education but also the values Western cultures where English language is primarily used. As a result, cultural understanding was used for improving a broader vision among teachers. Other key objectives of the SIG included the improvement of English language teaching at Turkish schools, the development of learning strategies for language learning and the organization of seminars, training programs and conferences to train young teachers, to renew the knowledge of experienced teachers and to share experiences. Future plans included establishing a "Reward System" for the teachers and good language learners with the aim of creating and sustaining a "life-long learning motivation" in ELTers.

In order to achieve the above goals and objectives, the SIG leaders would provide the members with (i) conferences and seminars for ELTers, covering topics which include primary, secondary and college practices and teacher-parentadministrator training issues, and (ii), a bi-annual published newsletter including articles on theory and methodology involved in using TQE in school and at the ELT classroom.

The initial outcome of the SIG within the first years was the formation of sub-committees in various universities to act as regional leading organizations. For instance, the "Kültür Q-ELT Group" was formed in 2000 with 33 members working for the Kültür University and Kültür Schools. In May 2001, a second sub-group was formed at I $1 \mathrm{k}$ University. The chair of the Foreign Language Department of that University offered a very interesting collaboration. She would send some of the native speakers of that department staff to the Anatolian universities to make their students meet native speakers of English language. Many "Q-ELT days and afternoons" were organized in different cities including Bursa Uludağ University, Adana Çukurova University, and Bolu İzzet Baysal University. Some of them were conducted in large conference halls for groups as large as 500 participants; publishers like MacMillan and Oxford supported these events.

The results of the surveys which were applied at the end of each "SIG Q-ELT" seminar revealed the impacts upon the ELTers: The ELTers were very much interested in trying new approaches in their classes; however, it was clearly understood that they could not find the necessary support from their administrators. School principals wanted to place the heavy burden of paperwork of TQM on the teachers in addition to their own 
subject matter preparations and that generated reluctance. In fact, the kind of paperwork applied in Turkey never exists in other countries applying TQM such as India, Nepal or Japan. That was one of the mistakes made by the Ministry authorities in early 2000s. Besides, the university entrance examination system in Turkey gives more importance to some subject areas like maths, science and social sciences. As a result, not only students but also parents focus on test-based exam preparations, and more importance is given to those subjects. This is a big problem for the teachers of culture-based courses, potentially creating negative feelings and killing their intrinsic motivation.

Those seminars which were titled as "Share \& Care Meetings" went on until 2004, and then came to an end. One of the main reasons was the difference in the policy of the Association after the change of the governing board with the elections. It was the end of "Q-ELT" activities. Thus, due to the great need for quality improvement efforts in Turkish schools, I started collaboration with the teachers of other branches such as maths and social sciences to create similar awareness among them.

\section{The Turkish center for schools of quality}

It was greatly necessary to include all the other subject area teachers and also school principals in the quality improvement efforts in addition to ELTers. In response, I co-founded the Turkish Center for Schools of Quality with the international Quality expert John Jay Bonstingl in 1999 as a Network. The Center started "TQM Awareness Seminars" for school people with the permission of the Ministry. Feedback from the participants was hopeful. Educational District Directors were organizing the seminars as in-service training courses and I was travelling throughout the country to enlighten them.

In 2001, I started İmece Circles projects in my courses which are mostly known as Students' Quality Circles (SQCs). After four years, "İmece Circles (Turkish SQCs)" Project received an award by the World Bank in the "2005 Turkey Creative Development Projects Competition.”

In the same year, the Ministry of Education prepared and started a new curriculum for elementary and secondary schools which is based upon constructivist philosophy instead of behaviourism, which had been the previous philosophy. Teachers were asked to learn about emerging technologies, including project-based teaching methodology. The Turkish Center for Schools of Quality started a project partnership with Microsoft Turkey to train all leading teachers from every district of Turkey, based upon "Microsoft Innovative Teachers Program." This project was administered through the partnership with the Educational Technologies Department of the Ministry.

The Turkish Center for Schools of Quality is a Networking system. All the developments are shared through its website and Blog to make effective use of educational technology (www. kaliteokullari.com). Each year, the strategic plan is renewed. Mission, vision, policy, strategies and the advisory board members were shared within the cyber world. The main target of the Turkish Center was to help every school in Turkey to become a true "school of quality." To realize this goal, quality awareness seminars would be given. Similarly, conferences and projects would be held and a collaborative movement would be created with national and international organizations to share the quality improvement efforts and success stories of Turkey at the conventions and annual meetings of the World Council for Total Quality \& Excellence in education (WCTQEE) which was founded by 25 countries in City Montessori School, Lucknow, India. I have served as Director General of the Turkish branch of WCTQEE since 2003.

The Turkish Center for Schools of Quality has been assisting teachers and principals through face-to-face in-service training programs since its foundation. More than 25,000 teachers were trained in TQM through Quality seminars in different towns and cities of Turkey until 2008. Those seminars also included lecturers, NGO leaders and college students. After that time, the Center went on supporting educators mostly with e-projects as a Network. For a sample international ICT Project, please visit the website of ICT Seagulls (www.bilisimcimartilar.com).

The Turkish Center also organizes international conferences. For instance, it organized the " $11^{\text {th }}$ 
International Convention on Students' Quality Circles" in Istanbul in 2008. The " $15^{\text {th }}$ Annual Conference of Human Dignity and Humiliation Studies" was held in Istanbul in 2010. Both events hosted quality experts to inform the Turkish educators and to share the recent developments.

\section{Quality courses in various universities to train future teachers}

According to the "Quality Philosophy," leadership is the most important factor for the success of the quality improvement efforts in any organization. The leader establishes a gracious and hospitable place to work together (Bonstingl, 2001). Teachers, being the leaders of their students, should be wellinformed about the quality philosophy and its classroom applications for the sake of creating a change environment in their classrooms and being good models for their followers.

Teachers should be attracted towards the change process. That begins from the university level. Teacher candidates should be prepared by the Faculty of Education for quality practices before the first day of their teaching careers. This can be considered as the pre-service training part of the teacher training while the "Quality Awareness" seminars are regarded as the in-service training part of the whole process.

I designed and instructed a "Quality in ELT" course for the senior students of the FLED (Department of Foreign Languages Education) for 8 terms between the years of 1998 and 2002. Teacher trainees were trained in TQM and its applications to ELT classrooms. At the end of each term, they presented their SQC projects to experienced teachers through regional conferences. It was a very motivating activity for the teacher candidates. Through that course, they felt themselves ready for their future jobs and they went a step beyond the present teachers. After their graduation they became the members of "TQM Commissions" in their new schools.

A similar course was opened at Yeditepe University under the name of "Quality in Education" for two terms. Still another was given as an MBA Course in Bahçeşehir University. To include the other professionals into the quality issues, another course was proposed to the administration of
Ylldız Technical University in the 2003 and 2004 academic years. An elective course named "Personal Quality and Leadership" was opened for the Engineering and Architecture students there. Each term, around 50 students elected the course and they learned how to apply personal quality strategies into their lives (Bonstingl, 2004). Students have learned how to conduct Students' Quality Circles (SQCs) and then to present them before the audience.

Since then, I have been designing new courses for the newly appeared needs of teachers, such as "Innovative Teachers," "Non-violence and Dignity in Education." However, the essence of all courses is quality based upon PDCA Mindset. Students give very positive reflections at the end of the terms, and most of the graduates still keep in touch with me for more collaborative projects with their own students.

\section{Outcomes of quality efforts}

"TQM in education is not a panacea," as Arcaro (1995) said. It is not a magic wand to eliminate the problems from the school or from the classroom. It requires time and effort. Once TQM is an essential part of the school or classroom culture, problems seem more manageable; more students take greater responsibility for their learning. Quality in education is what makes learning a pleasure.

School leaders and teachers should apply Quality practices in their work with students because creating a Quality environment is the main and the first mission of all adults to prepare the coming generations for success. Indeed, the function of school is very important for the Quality era in which we live.

Greenwood \& Gaunt stated that TQM was a vehicle for change (1994). The most important factor, the commitment of the leader and top management to the quality process, must be total and evident. The dedication must aim at changing the philosophy, to improve the process, to satisfy the partners, and to ensure the survival. In order to realize these, the leader should involve everyone, train everyone, lead from the top, set up "Quality Improvement Teams" and develop Action Plans.

This concept of collaboration is mentioned as "Support Teams" within the glossary of Bonstingl 
(1998). Whereas the member countries of the World Council for Total Quality and Excellence in Education (WCTQEE) call team working supported with quality tools "Students' Quality Circles (SQCs)," I call it "İmece Collaboration Circles" to localize the term. "Imece" is a core value for Anatolian people while solving problems and doing their local jobs like harvesting, marriage organization and so on. Until now, almost 2,000 mece Circles have been trained and guided by me.

\section{Results of teacher training courses}

After each training program a survey is conducted and feedback is completed from the participants. It is interesting that between the years of 1998 and 2004, 10\% of the participating teachers were resisting to TQM Philosophy and its implementations; that rate increased to $35 \%$ in 2011. The result cannot be underestimated. While many countries in the world are focusing more on TQM, what is happening in Turkey? What causes them to resist?

1. The reasons seem to be stemming from the managerial style of the administrators. From the very beginning, it was presented to teachers as if it were a top-down system, even though it was the main need of teachers to improve quality level in their environments. Principals were not well-informed about the principles of TQM and they were not able to develop the necessary leading skills to support the school people about the quality implementations.

2. Budget has become a big problem for state schools. Experts were not from the educational field and they guided schools as if they were business organizations.

3. Turkish people are somehow against the terminology of "customer" for the educational settings. They do not want to think their students/children as customers, because that word is linked with money according the Turkish way of thinking. "Money" and "educating students" are rarely connected. Education is something gained through the support of the state and for years it was free. This seems to be one of the main reasons for resistance.

4. Leadership is ignored in some schools. School principals invite quality experts to their schools to learn the essence, but many of the principals never attend the seminar. That results in wrong implementations, and gives the impression to the attendees that this is not important.

5. Teacher trainees show great interest in the new system, whereas the experienced ones resist. Older teachers consider TQM activities as a waste of time and energy and they stick to their traditional approaches. This is not the case for ELTers in many schools.

\section{Some final remarks}

Quality leadership necessitates managing change effectively. In order to be successful in that transforming process, either as a principal or a teacher, learning as much as possible about TQM and its application to education is essential. Then, the second step is making a personal dedication to the Quality Philosophy. Demonstrating Quality leadership to staff members, associates, students, parents, and the entire community by "talking your walk and walking your talk" is one of the keys. Building strong networks of support for the change is required to build commitment (Bonstingl, 2001).

I started quality improvement efforts with ELTers in my environment. As one of the teacher trainers of that subject area, I have been aware of the leading power of language teachers. Communication skills are strong change agents, and in an ELT classroom the teacher never allows her/his students to sit at their desks silently while $s$ unapplied knowledge. S/he leads students in the creation of a learning atmosphere. In the spirit of the Quality Philosophy, the program continually evolves and develops through the active participation of students. There is a strong collaboration among the members of the classroom through pair- and group-work activities. ELT teachers, who are practised in leadership and communication skills, lead the students into the successful attainment of a foreign language. In short, it can be said that ELT teachers have already focused on quality improvement techniques because they are intrinsic to success in their field. They are trained as professionals who are always looking for new techniques and approaches to teach a foreign language in the most effective way. It is just this 
point that ELT concentrates on "Quality."

All teachers in the Quality movement should act as a "guide on the side" than a "sage on the stage." Working consciously and continuously to create environments that challenge their students to develop their potentials to the fullest. Teachers, we know, are the leaders of the future leaders of our world. Therefore, educators' 21-century _Quality skills_ should be developed through pre-service and in-service programs.

If any organization wants to be successful at a "Quality journey," the following should be kept in mind during the change process: getting better at everything, being successful by working together, and looking at success as a continual process that is seen in everything you do (Greenwood \& Gaunt, 1994). The ultimate goal of all school people is to improve the educational experiences and achievements of students we serve in schools. In this, Quality must be essential focus.

\section{The Author}

Hayal Köksal, PhD, is a teacher, trainer, and scholar of educational sciences. After working as a teacher of English in secondary schools for 10 years, she moved to university as a teacher trainer. Her interest in TQM started with her doctoral studies in 1990. In 1999, she co-founded the Turkish Center for Schools of Quality with Prof. J.J.Bonstingl and in 2003 she became the Director General of Turkey of WCTQEE established in India. She has been a part-time instructor at the Educational Faculty of Boğaziçi University and a visiting fellow of London Kingston University. She has written 14 books and more than 100 articles about TQM, through which she has helped create awareness about Quality education in Turkey and beyond. Email: hayal@hayalKöksal.com.

\section{References}

Arcaro, J. (1995). Creating quality in the classroom. New York: Kogan Page.

Blankstein, A. M. (1996). Why TQM Can't Work? In Contemporary Education, 67, Winter 1996, 65-68.

Bonstingl, J. J. (2001). Schools of quality (3rd ed.). Thousand Oaks, CA: Corwin. Comer, J. P.

---. (2001). Experiencing a true school of quality.
Paper presented at the Third International and Invitational Quality Education Leadership Retreat, Maui, Hawaii, 2-5 July, 2001.

Brassard, M. (1996). The memory jogger plus+: featuring the seven management and planning tools. 2nd edition. Methuen, MA: GOAL/QPC.

Cafoglu, Z., (1997). TQM in education. Ankara: Avni Akyol Foundation Books.

Deming, W. E. (1986). Out of the crisis. Cambridge. Boston: MIT Center for Advanced Engineering Study.

Fields, J.C. (1994). Total quality for schools, ASQC Quality Press, USA.

Greenwood, M.S., Gaunt, H.J.. Greenwood, M.S. and Gaunt, H.J. (1994) Total quality management for schools. London: Cassell.

Hunt, V.D. (1992). Quality in America, Homewood, IL: Business One Irwin.

Kanji, G.K. (1995). TQM Leadership. In TQM Proceedings of the First World Congress, London: Chapman \& Hall.

Kavrakolu, . (2000). Total quality management. Istanbul: KalDer Publications.

Keleman, K.S. Peter Haug. (1996). Introduction of Total Quality Management into the Process of Teaching management. Journal of Management Education, 3, 319-340.

Köksal, H. (1998). TQM on the way of being a school of quality. Istanbul: Globus Publishing.

---. (1999). Why quality in ELT? NGED-News in Brief, 3, 1999, 3.

---. (2001). Quality in ELT textbook. Istanbul: Bo aziçi University.

Peters, T. (1988). Thriving on chaos, London: Pan Publications.

Sallis, S. (1996). Total quality management in education. London: Kogan Page. 